\title{
Exceptional species richness of ciliated Protozoa in pristine intertidal rock pools
}

\author{
Genoveva F. Esteban*, Bland J. Finlay \\ School of Biological \& Chemical Sciences, Queen Mary, University of London, London E1 4NS, UK
}

\begin{abstract}
Marine intertidal rock pools can be found almost worldwide but little is known about the microscopic life forms they support, or the significance of regular tidal inundation. With regard to ciliated Protozoa in rock pools, little progress has been achieved since 1948, when the question was first posed as to how a community of ciliates can remain relatively constant in a rock pool that is flushed twice a day. Here we show that local ciliate species richness is very high and that it may persist over time. This elevated species richness can be attributed to ciliate immigration with the incoming tide, and also to the resident ciliate community that withstands tidal flushing. A $15 \mathrm{~cm}$ deep intertidal rock-pool no bigger than $1 \mathrm{~m}^{2}$ on the island of St. Agnes (Scilly Islands, UK) contained at least 85 ciliate species, while a $20 \mathrm{~cm}$-deep rock pool with roughly the same area on Bryher (also in the Scilly Islands) yielded 75 species. More than $20 \%$ of the global number of described marine interstitial ciliate species was recorded from these rock pools. We explore the paradox of a persisting community assembly living in an ecosystem that is physically highly dynamic.
\end{abstract}

KEY WORDS: Marine ciliates · Marine biodiversity $\cdot$ Intertidal rock pools

\section{INTRODUCTION}

The question of how a community of ciliate species can remain in an environment that is mixed and replaced with water from the open sea twice a day was posed more than half a century ago by Fauré-Fremiet (1948), following his study of the ciliate community in a rocky intertidal basin close to his laboratory in Concarneau (France). As far as we are aware, this is the only investigation of its kind recorded in the scientific literature. Fauré-Fremiet (1948) found only a handful of ciliate species, but made 2 discoveries - that the community composition remains relatively constant over time, although the water is renewed with every tide, and (in the case of the ciliate Strombidium oculatum), the existence of a 'tidal rhythm'. The latter has been investigated in more detail (Jonsson 1994, Montagnes et al. 2002), but the study of community assembly, ciliate species richness in rocky intertidal pools, and the adaptations that allow them to thrive there, largely remain a 'closed book'. Here we report some of our recent observations and discoveries concerning the ecology and natural history of ciliates in rock pools.

\section{MATERIALS AND METHODS}

Sampling sites. We studied intertidal rock pools at pristine sites on the Isles of Scilly (also known as Scilly Islands or 'Scillies'), an archipelago of about 200 islands and rocks, of which only 5 are inhabited, located $45 \mathrm{~km}$ off Land's End (the most southerly point of the United Kingdom mainland) (Fig. 1). The islands are low lying and mainly composed of flat topped granite. We selected 2 islands to investigate the ciliates living in intertidal rock pools, i.e. pools that are submerged at high tide and also subjected to the force of Atlantic 'breakers'. The islands were Bryher, whose west coast faces the full force of the 'breakers', and St. Agnes. Three rock-pools were investigated: 1 on a beach at St. Agnes (Fig. 2A,B), and 2 at Bryher-one on the beach, and the other amongst an area of large rocks (Fig. 2C,D). We collected the samples on 23 and 25 October 2005, respectively, and examined them daily over a period of $5 \mathrm{~d}$. We aimed to retrieve and identify as many ciliate species as possible, and to do this, we collected and subsequently handled the samples in a 


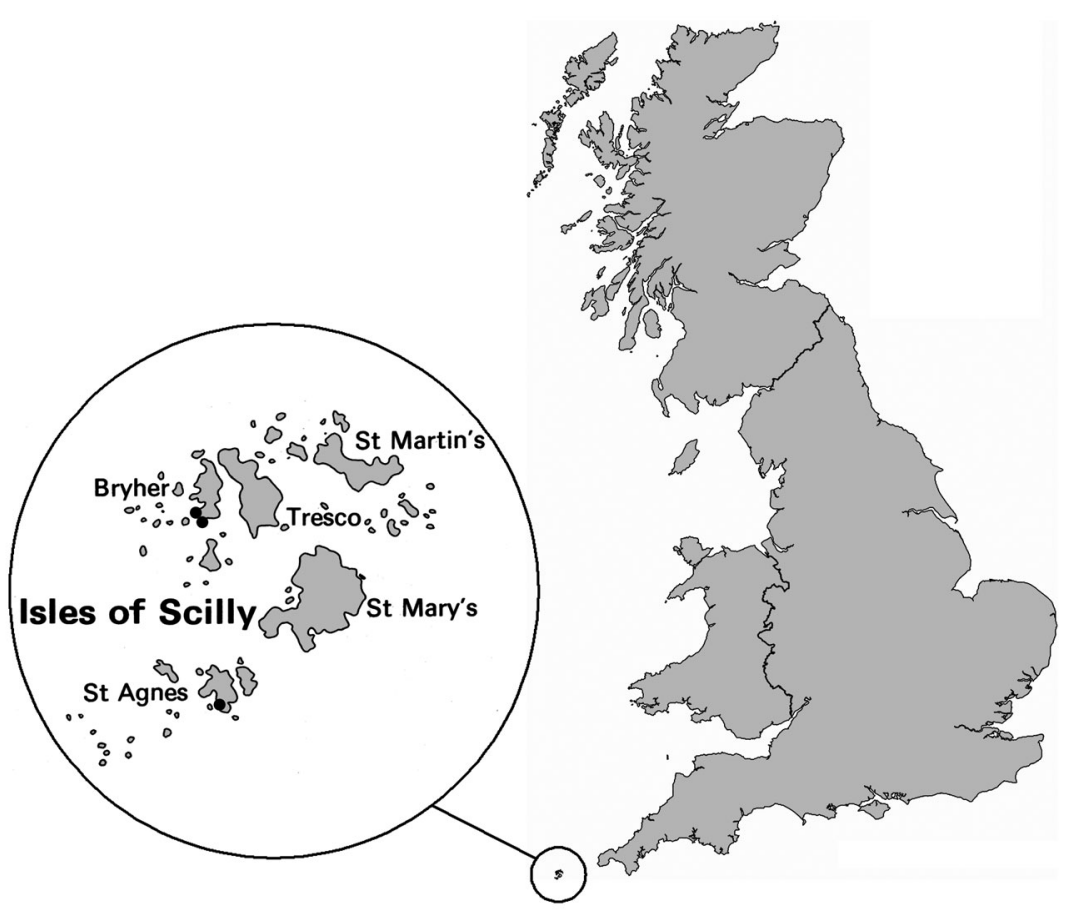

Fig. 1. Location of the Isles of Scilly (UK). •: sampling sites on St. Agnes and Bryher

variety of ways. For sample collection we used (1) sterile, $50 \mathrm{ml}$ centrifuge polypropylene tubes, (2) Nalgene bottles $(250 \mathrm{ml})$, and (3) sterile $25 \mathrm{~cm}^{2}$ polystyrene cell culture flasks containing $2 \mathrm{ml}$ of soil extract medium (Catalogue of UK National Culture Collection, UKNCC 2001). Rock pools containing a layer of fine sand were sampled with corers (internal diameter $2 \mathrm{~cm}$ ), and the samples placed in sampling tubes. We used sterile, single-use pipettes to remove sediment and other 'material' from crevices, rock surfaces, and the floor of each rock pool. This material was a combination of mainly fine sand, algae, and pieces of decomposing macroalgae. Some was thoroughly bonded with the rock surface and could be removed only with a small spatula. Thereafter it was placed in sterile sampling tubes, leaving a head space of a few $\mathrm{cm}$. A variety of marine macro-algae was also collected for examination of sessile Protozoa. The granulometry of the sand in the rock pools ranged from very fine to slightly coarse. The depth of the rock pools varied from 10 to $20 \mathrm{~cm}$ and they were generally up to $2 \mathrm{~m}$ in length with a maximum area of up to $1 \mathrm{~m}^{2}$ (Fig. 2B,D). All samples were investigated in a small laboratory on shore as soon as possible after sampling. We also set up manipulation experiments (e.g. Finlay et al. 1996, Fenchel et al. 1997) based on a variety of culture media, oxygen and redox gradients (to encourage growth of anaerobic ciliates) and various culture vessels. For each 'manipulation', we used $2 \mathrm{ml}$ subsamples of the original samples.
Cultures for incubation were prepared immediately after collection by placing $10 \mathrm{ml}$ subsamples in culture vessels with $2 \mathrm{ml}$ of soil extract medium, to encourage rare and encysted forms (if any) to grow out and be recorded. All samples and cultures were kept in a $20^{\circ} \mathrm{C}$ incubator throughout the investigation. Fresh samples were assessed every day for previously unrecorded ciliate species during our stay on the Scillies, and twice weekly thereafter. The assessment of species richness was based on $1 \mathrm{ml}$ subsamples of the original samples and cultures, and picking out individual specimens. We followed the ice extraction method of Uhlig (1966) to extract the larger ciliates without damaging them.

Ciliate species were identified after impregnating specimens with silver (Fernández-Galiano 1994, Esteban et al. 1998) when sufficient cells were available. Identification of species represented by few individuals (e.g. inadequate for confirmation with silver impregnation) were identified to putative species of the living form with recourse to our extensive bibliography of previously published marine material (e.g. see Esteban \& Finlay 2004) and other well-established identification guides, e.g. Kahl (1935). Single specimens of ciliates observed once only were identified to genus level.

Electron microscopy. In order to investigate the bacteria upon which the rock-pool ciliates might feed, subsamples from the Bryher open-ocean rock pool were used to make shadow-cast direct preparations for transmission electron microscopy (TEM). Preparation, handling, and examination of samples for TEM was carried out by K. J. Clarke (Freshwater Biological Association, UK). Replicates were washed with distilled water and centrifugation to remove the salts. The washed material (a 3 to $4 \mu$ l-sized drop) was placed directly on Formvar-coated specimen grids, then fixed with $\mathrm{OsO}_{4}$ vapour, air-dried at room temperature, and finally shadowed with chromium. Examinations were made using a JEOL 100CX TEMSCAN.

Data handling. In order to assimilate and compare data sets, we calculated size-frequency distributions (SFDs). The main advantage of using SFDs with a logarithmic body size axis is that the shape of the distribution can immediately be compared with other distributions to determine (e.g.) where the modal size class is and whether the distribution is skewed towards large or small species. We compared the SFDs for the rock-pool ciliates with the SFDs of (1) the 168 species of ciliates we recorded from the Isles of Scilly, (2) 170 ciliate spe- 

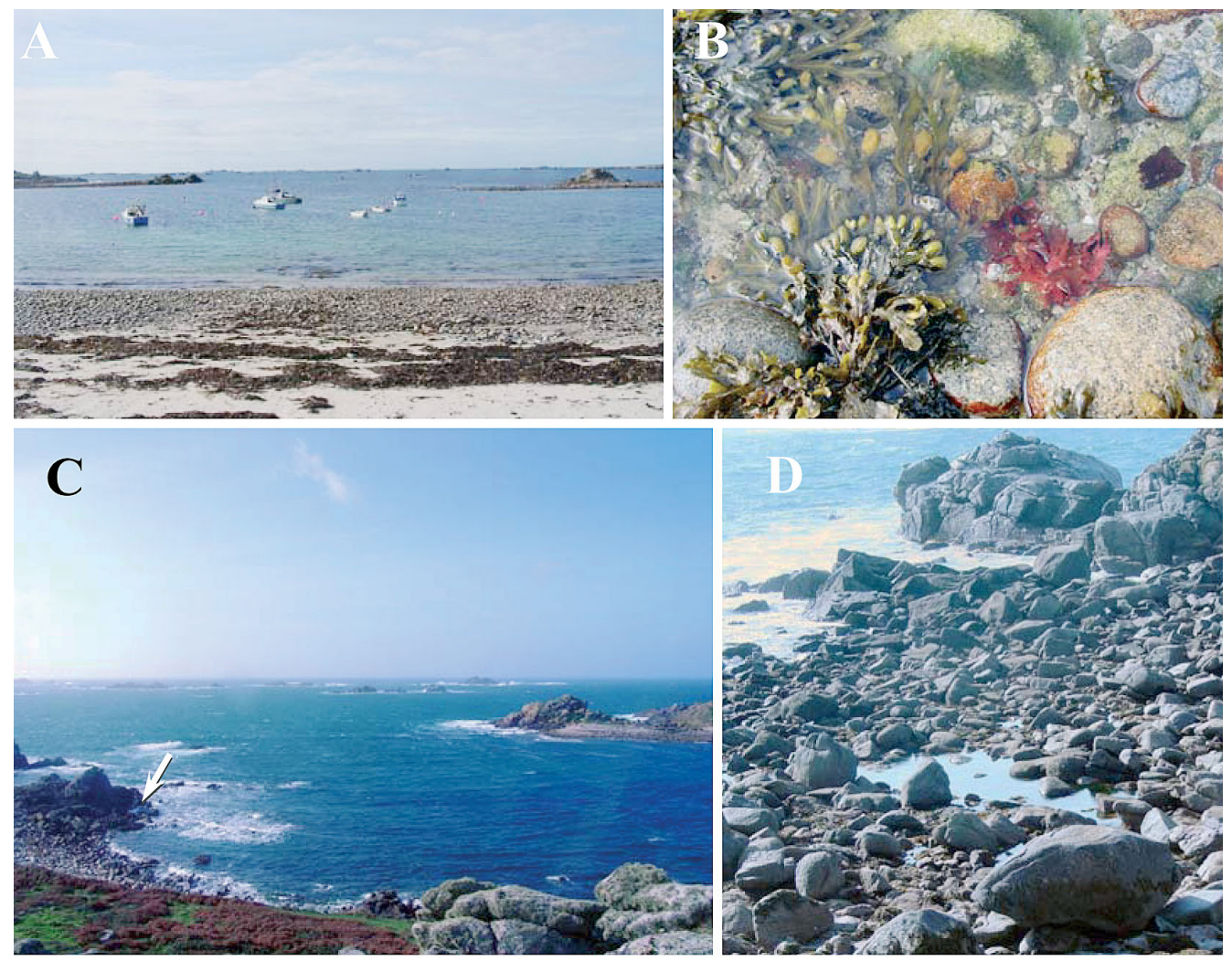
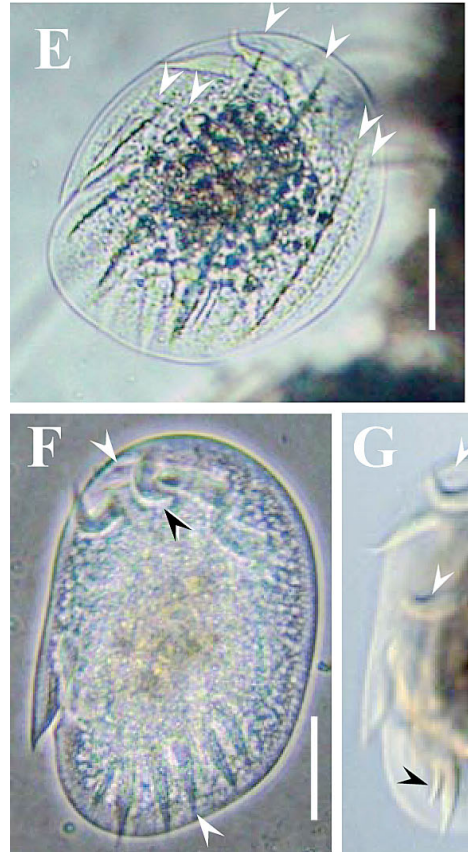
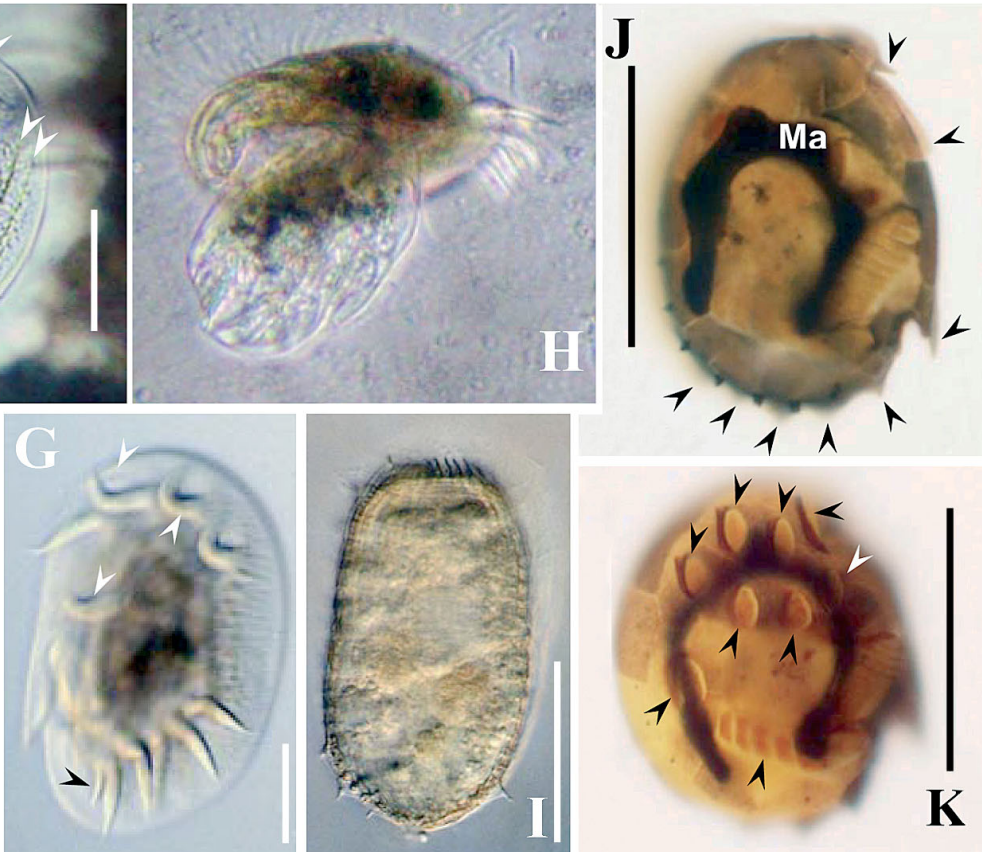

Fig. 2. (A,B) St. Agnes: (A) beach with rocks and sand, (B) close-up of rock pool investigated. (C,D) Bryher: (C) open-ocean rockycoast of Bryher (arrow shows pool sampled), (D) close-up of rock pool. (E-G) Live specimens of Aspidisca magna (light microscopy): (E) conspicuous ribbed dorsal surface (arrowheads); (F) ventral surface of cell (phase-contrast), top arrowhead indicates tight group of frontal membranelles with cilia directed forward, middle arrowhead frontoventral cirri (not all are in focus on this field plane) and bottom arrowhead transverse cirri; (G) ventral surface (Nomarski interference contrast). (H) Diophrys scutum (brown specimen) trying to ingest large A. magna. (I) Coleps pulcher (Nomarski interference contrast). (J,K) Specimens of Aspidisca pulcherrima impregnated with silver-carbonate; in (J) arrowheads indicate cytoplasmic spines (hazy in background) that characterise this species (Ma = horseshoe-shaped macronucleus); in (K) ventral surface shows arrangement (arrowheads) of frontoventral cirri, frontal membranelles and transverse cirri. All scale bars $=50 \mu \mathrm{m}$ 
cies from Nivå (a brackish, estuary-like habitat north of Copenhagen, Denmark, that is permanently covered by the waters of the Øresund; Finlay \& Fenchel $2004 a, b)$, and (3) the global list of interstitial marine ciliate species taken from Hartwig (1980) and Carey (1992). We selected (2) and (3) because they are the only data sets available that include a full checklist of species and the body length of each species. The Excel file for Nivå includes data for 170 ciliate species found in interstitial sandy sediment, and is available on-line (Finlay \& Fenchel 2004b). We compiled a further Excel file for the recorded global list of interstitial marine ciliate species according to Carey (1992). The preface of Carey (1992) remarks that 'the book is the first identification guide to include all ciliate species recorded from marine sands'. Although a few new species have been discovered since the book was published, their number is not great enough to significantly alter the size-frequency distributions. We used the 826 species from Carey (1992) after removing those species whose usual habitat is not marine (e.g. Loxodes spp.) We assigned a geometric mean size to each species based mainly on body sizes given in Carey (1992), and the data set thus prepared can be used as a global inventory of interstitial ciliates species. We then classified the data of body length into 11 logarithmic size-classes, 4 size classes per log cycle ranging from 7.5 to $2370 \mu \mathrm{m}$. Ciliates were allocated to their appropriate size classes.

\section{RESULTS AND DISCUSSION}

Having investigated sandy sediment and water samples from 3 rock pools in the Scillies, we identified 168 marine ciliates to genus and/or species level. The samples from St. Agnes and from 1 of the 2 rock pools on Bryher yielded 85 ciliate species, and 75 species, respectively (Table 1) whereas the samples from Bryher's beach yielded 50 species (Table 1). The community in the rock pools is interesting because only 10 nominal species were recorded simultaneously from all 3 rock pools: Cyclidium glaucoma, Diophrys appendiculata, D. scutum, Euplotes elegans, Litonotus duplostriatus, Plagiopyla frontata, Pleuronema coronatum, Trachelostyla pediculiformis, Uronychia transfuga and Uropedalium pyriforme. This suggests that the remaining species richness in rock-pools is fairly heterogeneous. The ciliate Aspidisca magna (Fig. 2E-G) was common to both rock pools on Bryher but we did not observe it in rock pool samples from St. Agnes. The ciliates in the rock pool on the beach of Bryher were basically a mixed community of the species found in the rock pools of St. Agnes and Bryher. For the purpose of this investigation, we focus on these rock pools at St. Agnes and the open-ocean rock pool at Bryher be- cause they presented the highest species richness. The size-frequency distributions (SFDs, Fig. 3) for both rock pools are similar, even though that on St. Agnes had a greater number of larger ciliate species (e.g. tracheloraphids, geleids).

The St. Agnes rock pool (Fig. 2A,B) is located on a beach that is partly rock and partly sand. In contrast, the rock pool on Bryher faces the open ocean and the full force of the breakers (Fig. 2C,D). At St. Agnes, tidal waves regularly wash the sand on the beach surrounding the rock pool, and this sand is probably the source of most of the ciliate species in the pool. As the rock pool also has a well-developed layer of fine sand that has accumulated amongst the rocks and pebbles, the sand was assumed to offer a niche for immigrant benthic and interstitial ciliates. To test this, we carried out a general screening of the ciliate community from sand samples immediately above and around the rock pool, and found that $62 \%$ of those in the surrounding sand were also present in the pool. This value is almost cer-

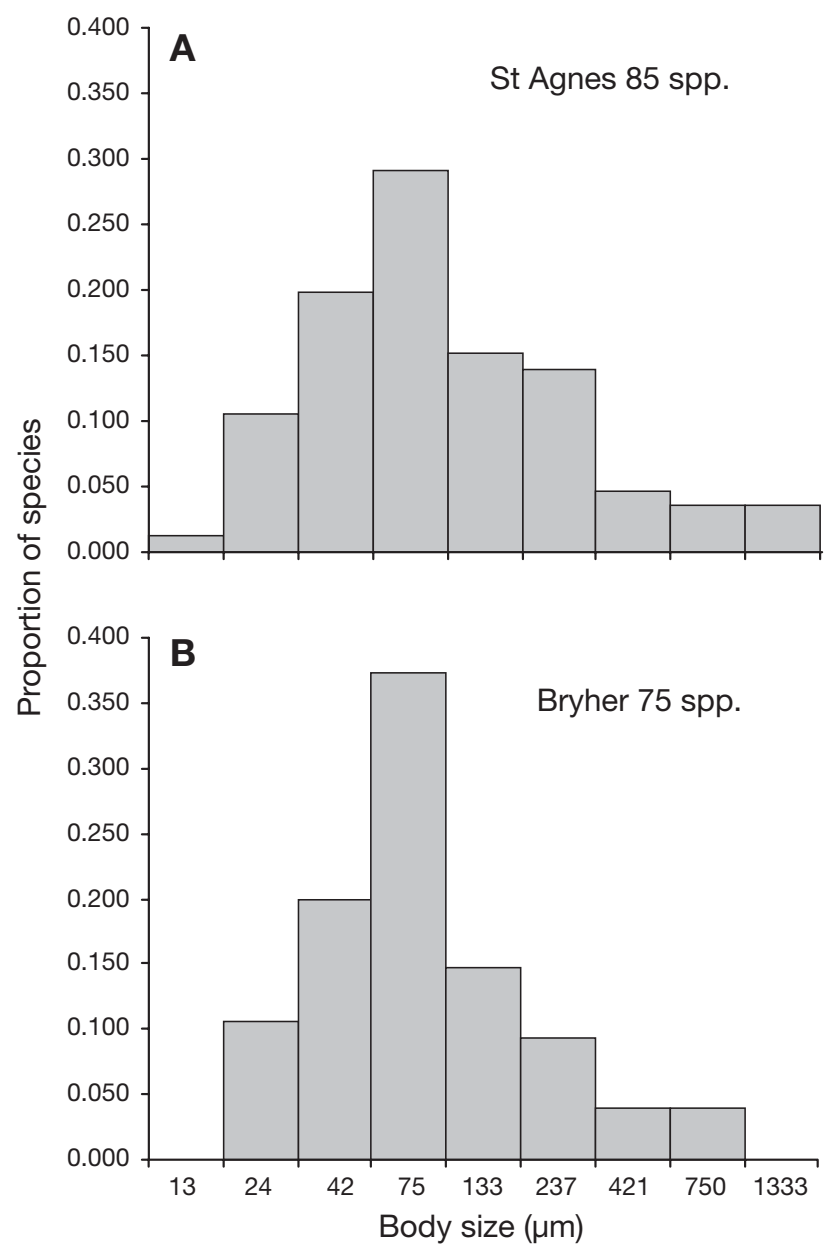

Fig. 3. Size frequency distribution of ciliate species recorded in 2 intertidal rock pools on Isles of Scilly. (A) St. Agnes; (B) Bryher (open-ocean rocks). Body size is geometric mean for each size class 
Table 1. Species of ciliated Protozoa retrieved from 3 pristine intertidal rock pools on Isles of Scilly (UK): SA: St. Agnes, rock pool on beach; BO: Bryher, open-ocean rock pool; BB: Bryher, rock pool on beach; x: present

\begin{tabular}{|c|c|c|c|c|c|c|c|}
\hline Ciliate species & SA & $\mathrm{BO}$ & $\mathrm{BB}$ & Ciliate species & SA & $\mathrm{BO}$ & BB \\
\hline Acineria sp. & & & $\mathrm{x}$ & Loxophyllum sp. 1 & $\mathrm{x}$ & $\mathrm{x}$ & $\mathrm{x}$ \\
\hline Acineta tuberosa & & $\mathrm{x}$ & & Loxophyllum sp. $2(60 \mu \mathrm{m})$ & $\mathrm{x}$ & $\mathrm{x}$ & $\mathrm{x}$ \\
\hline Actinotricha saltans & $\mathrm{x}$ & & & Loxophyllum sp. $3(250 \mu \mathrm{m})$ & $\mathrm{x}$ & & \\
\hline Actinotricha thiophaga & $\mathrm{x}$ & & $\mathrm{x}$ & Mesodinium pulex & & & $\mathrm{x}$ \\
\hline Anigsteinia clarissima & & $\mathrm{x}$ & & Mesodinium rubrum & & & $\mathrm{x}$ \\
\hline Aspidisca dentata & $\mathrm{x}$ & & & Metacystis elongata & & $\mathrm{x}$ & \\
\hline Aspidisca magna & & $\mathrm{x}$ & $\mathrm{x}$ & Metanophrys sp. & & & $\mathrm{x}$ \\
\hline Aspidisca major & $\mathrm{x}$ & & $\mathrm{x}$ & Monodinium sp. & & $\mathrm{x}$ & \\
\hline Aspidisca cf. polypoda & $\mathrm{x}$ & $\mathrm{x}$ & & Nassulid-brownish $(70-80 \mu \mathrm{m})$ & & $\mathrm{x}$ & \\
\hline Aspidisca pulcherima & $\mathrm{x}$ & & & Oxytricha sp. & & & $\mathrm{x}$ \\
\hline Aspidisca robusta & $\mathrm{x}$ & & & Paraspathidium fuscum & $\mathrm{x}$ & & \\
\hline Aspidisca cf. turrita $(50 \mu \mathrm{m})$ & $\mathrm{x}$ & & & Paraspathidium sp. & & & $\mathrm{x}$ \\
\hline Aspidisca sp. & $\mathrm{x}$ & & $\mathrm{x}$ & Peritromus faurei & & $\mathrm{x}$ & $\mathrm{x}$ \\
\hline Bryophyllum sp. $(70 \mu \mathrm{m})$ & & & $\mathrm{x}$ & Peritromus gigas $(350-400 \mu \mathrm{m})$ & & $\mathrm{x}$ & \\
\hline Cardiostomatella vermiforme & $\mathrm{x}$ & $\mathrm{x}$ & & Peritromus ovalis & & $\mathrm{x}$ & \\
\hline Chaenea clavata & & $\mathrm{x}$ & & Philasterides/Metanophrys sp. & & $\mathrm{x}$ & \\
\hline Chilodonella sp. & & $\mathrm{x}$ & & Placus sociale & $\mathrm{x}$ & & \\
\hline Chlamydodon sp. & & $\mathrm{x}$ & & Plagiocampa marina & $\mathrm{x}$ & $\mathrm{x}$ & $\mathrm{x}$ \\
\hline Cohnilembus cf. longivelatus & & $\mathrm{x}$ & & Plagiopogon loricatus & $\mathrm{x}$ & & \\
\hline Cohnilembus stichotricha & $\mathrm{x}$ & & & Plagiopyla frontata & $\mathrm{x}$ & $\mathrm{x}$ & $\mathrm{x}$ \\
\hline Coleps pulcher & & $\mathrm{x}$ & & Pleuronema coronatum & $\mathrm{x}$ & $\mathrm{x}$ & $\mathrm{x}$ \\
\hline Coleps tesselatus & & $\mathrm{x}$ & $\mathrm{x}$ & Pleuronema marinum & $\mathrm{x}$ & & $\mathrm{x}$ \\
\hline Condylostoma arenarium & $\mathrm{x}$ & $\mathrm{x}$ & & Podophrya sp. & $\mathrm{x}$ & & \\
\hline Condylostoma magnum & & & $\mathrm{x}$ & Porpostoma/Philasterides sp. & & & $\mathrm{x}$ \\
\hline Condylostoma sp. & & $\mathrm{x}$ & & Prorodon discolor & & $\mathrm{x}$ & \\
\hline Cothurnia sp. on Gammarus sp. & & $\mathrm{x}$ & & Prorodon marinus & & $\mathrm{x}$ & $\mathrm{x}$ \\
\hline Cristigera cirrifera & $\mathrm{x}$ & $\mathrm{x}$ & & Prorodon morgani & $\mathrm{x}$ & & \\
\hline Cristigera media & $\mathrm{x}$ & & $\mathrm{x}$ & Prorodon teres & & & $\mathrm{x}$ \\
\hline Cristigera phoenix & $\mathrm{x}$ & & & Protocruzia pigerrima & & $\mathrm{x}$ & \\
\hline Cristigera setosa & $\mathrm{x}$ & $\mathrm{x}$ & & Prototrachelocerca caudata & $\mathrm{x}$ & $\mathrm{x}$ & \\
\hline Cristigera vestita & $\mathrm{x}$ & & $\mathrm{x}$ & P. cf. fasciolata & $\mathrm{x}$ & & \\
\hline Cryptopharynx setigerus & $\mathrm{x}$ & $\mathrm{x}$ & & Pseudokeronopsis rubra & $\mathrm{x}$ & $\mathrm{x}$ & \\
\hline Cyclidium citrullus & & $\mathrm{x}$ & & Remanella margaritifera & $\mathrm{x}$ & & $\mathrm{x}$ \\
\hline Cyclidium glaucoma & $\mathrm{x}$ & $\mathrm{x}$ & $\mathrm{x}$ & Remanella rugosa & $\mathrm{x}$ & & $\mathrm{x}$ \\
\hline Dexiotricha sp. & $\mathrm{x}$ & & & R. rugosa var. unicorpusculata & & & $\mathrm{x}$ \\
\hline Diophrys appendiculata & $\mathrm{x}$ & $\mathrm{x}$ & $\mathrm{x}$ & Rimostrombidium cf. conicum & $\mathrm{x}$ & & \\
\hline Diophrys histrix & & $\mathrm{x}$ & & Sonderia cyclostoma & $\mathrm{x}$ & $\mathrm{x}$ & \\
\hline Diophrys scutum & $\mathrm{x}$ & $\mathrm{x}$ & $\mathrm{x}$ & Sonderia mira & & $\mathrm{x}$ & \\
\hline Discotricha papillifera & & $\mathrm{x}$ & & Sonderia vestita & & $\mathrm{x}$ & \\
\hline Dysteria appendiculata & & $\mathrm{x}$ & & Spathidium cf. extensum & $\mathrm{x}$ & & \\
\hline Dysteria cf. calkinsi & & & $\mathrm{x}$ & Spathidium sp. 1 & & $\mathrm{x}$ & \\
\hline Dysteria monostyla $(200 \mu \mathrm{m})$ & $\mathrm{x}$ & $\mathrm{x}$ & & Spathidium sp. 2 & & $\mathrm{x}$ & \\
\hline Dysteria pusilla & & $\mathrm{x}$ & & Strombidium oculatum & & & $\mathrm{x}$ \\
\hline Dysteria recta & $\mathrm{x}$ & & & Strombidium sulcatum/ & & & \\
\hline Dysteria sp. & $\mathrm{x}$ & & & Pelagostrombidium simile & $\mathrm{x}$ & $\mathrm{x}$ & \\
\hline Enchelyodon elongatus & $\mathrm{x}$ & & & Strombidium sp. 1 & $\mathrm{x}$ & & $\mathrm{x}$ \\
\hline Epistylis sp. & $\mathrm{x}$ & & & Strombidium sp. $2(35-45 \mu \mathrm{m})$ & & $\mathrm{x}$ & \\
\hline Euplotes cf. trisulcatus & & $\mathrm{x}$ & & Strombidium sp. 3 & & $\mathrm{x}$ & \\
\hline Euplotes charon & $\mathrm{x}$ & & & Strombidium sp. 4 & & $\mathrm{x}$ & \\
\hline Euplotes crassus var. minor & & $\mathrm{x}$ & & Tachysoma pellionella & $\mathrm{x}$ & & $\mathrm{x}$ \\
\hline Euplotes elegans & $\mathrm{x}$ & $\mathrm{x}$ & $\mathrm{x}$ & Trachelocerca cf. arenicola & $\mathrm{x}$ & & \\
\hline Euplotes eurystomus & & & $\mathrm{x}$ & Trachelocerca sp. $(100 \mu \mathrm{m})$ & & $\mathrm{x}$ & \\
\hline Euplotes harpa & & & $\mathrm{x}$ & Trachelophyllum cf. brachypharynx & & $\mathrm{x}$ & \\
\hline Euplotes moebiusi & $\mathrm{x}$ & & $\mathrm{x}$ & Tracheloraphis cf. longicollis & $\mathrm{x}$ & & \\
\hline Euplotes vannus & & $\mathrm{x}$ & & Tracheloraphis cf. margaritata & $\mathrm{x}$ & & \\
\hline Euplotes vannus var. balticus & & & $\mathrm{x}$ & Tracheloraphis cf. oligostriata & $\mathrm{x}$ & & \\
\hline $\begin{array}{l}\text { Euplotes sp. (with green algal } \\
\text { endosymbionts?) }\end{array}$ & & $\mathrm{x}$ & & $\begin{array}{l}\text { Tracheloraphis phoenicopterus } \\
\text { Tracheloraphis sp. }\end{array}$ & $\begin{array}{l}\mathrm{x} \\
\mathrm{x}\end{array}$ & & \\
\hline Euplotes sp. & $\mathrm{x}$ & $\mathrm{x}$ & & Trachelostyla caudata & $\mathrm{x}$ & & \\
\hline Frontonia marina & $\mathrm{x}$ & & $\mathrm{x}$ & Trachelostyla pediculiformis & $\mathrm{x}$ & $\mathrm{x}$ & $\mathrm{x}$ \\
\hline Frontonia sp. & $\mathrm{x}$ & & & Trimyema marinum & & $\mathrm{x}$ & \\
\hline Geleia orbis & $\mathrm{x}$ & & & Trimyema minutum & & $\mathrm{x}$ & \\
\hline Glauconema trihymene & $\mathrm{x}$ & & & Trochilia sigmoides & & $\mathrm{x}$ & $\mathrm{x}$ \\
\hline Gruberia lanceolata & & $\mathrm{x}$ & & Trochilia sp. & $\mathrm{x}$ & & \\
\hline Gruberia uninucleata & $\mathrm{x}$ & & & Trochilioides recta & $\mathrm{x}$ & $\mathrm{x}$ & \\
\hline Hartmannula acrobates & $\mathrm{x}$ & & & Uronema elegans & $\mathrm{x}$ & & \\
\hline Helicoprorodon sp. & & $\mathrm{x}$ & & Uronema marinum & & & $\mathrm{x}$ \\
\hline Hippocomus loricatus & $\mathrm{x}$ & & & Uronema nigricans & & $\mathrm{x}$ & \\
\hline Kentrophoros fasciolata & & $\mathrm{x}$ & & Uronychia transfuga & $\mathrm{x}$ & $\mathrm{x}$ & $\mathrm{x}$ \\
\hline Kentrophoros rubra & $\mathrm{x}$ & & & Uropedalium pyriforme & $\mathrm{x}$ & $\mathrm{x}$ & $\mathrm{x}$ \\
\hline Kentrophoros sp. $(100 \mu \mathrm{m})$ & $\mathrm{x}$ & $\mathrm{x}$ & & Vaginicola cf. amphora & $\mathrm{x}$ & $\mathrm{x}$ & \\
\hline Lacrymaria coronata & & & $\mathrm{x}$ & Vorticella elegans & $\mathrm{x}$ & & \\
\hline Lacrymaria delamarei & $\mathrm{x}$ & & & Vorticella cf. marina & $\mathrm{x}$ & & \\
\hline Lacrymaria olor & & & $\mathrm{x}$ & Vorticella sp. 1 & $\mathrm{x}$ & $\mathrm{x}$ & \\
\hline Lacrymaria sp. $(35 \mu \mathrm{m})$ & & & $\mathrm{x}$ & Vorticella sp. $2(30 \mu \mathrm{m})$ & $\mathrm{x}$ & $\mathrm{x}$ & \\
\hline Litonotus duplostriatus & $\mathrm{x}$ & $\mathrm{x}$ & $\mathrm{x}$ & Woodruffia rostrata & $\mathrm{x}$ & & \\
\hline Loxophyllum helus & $\mathrm{x}$ & & & Total number of species & 85 & 75 & 50 \\
\hline
\end{tabular}


tainly an underestimation, since more trachelocercid species (i.e. typical vermiform, narrow and elongated ciliates adapted to live amongst sand particles) were retrieved from the rock pool samples than from the neighbouring sand. In contrast, only $38 \%$ of the species recorded in the sands of St. Agnes were also recorded in the open-ocean rock pool of Bryher (where there is no surrounding beach).

Fig. 3 shows the SFDs for ciliates from the St. Agnes and Bryher rock pools. In both rock pools there was a higher proportion of ciliates in the 56 to $100 \mu \mathrm{m}$ size class (mean body size $75 \mu \mathrm{m}$ ). We compared both SFDs with the SFD of (1) all ciliate species recorded from all our Isles of Scilly samples (i.e. 168 species), (2) the SFD of ciliate species from Nivå (170 ciliate species; Finlay \& Fenchel 2004b), and (3) the SFD of the global list of world marine interstitial ciliates (826 species; see 'Materials and methods'). The results are shown in Fig. 4.

The SFDs for the 'local diversity' data sets, i.e. for each separate rock pool, for Nivå Bay, and the Isles of Scilly, indicate a higher proportion of smaller ciliates than does the SFD for the 'global diversity' data (SFD modes at 42 and $75 \mu \mathrm{m}$, respectively, i.e. 1 or 2 size classes smaller; see Figs. $3 \& 4$ ), indicating a lack of large species or a predominance of medium-sized species. Apart from Geleia orbis, no other geleiids (a genus with about 20 currently known species [Dragesco 1999]) were observed in the samples from the rock-pools investigated, but the results also seem to suggest that local habitats such as rock pools may have a limited number of available niches, especially for very large ciliates. It is also important to bear in mind that the data set we obtained from Carey (1992) is 5 times bigger than that from the study at Niva (Finlay \& Fenchel 2004b) and our own data set from the Scillies. A larger data set from the latter region would almost certainly produce a bell-shaped distribution, as in the Carey data set.

All ciliate species recorded from the second rock pool on Bryher (i.e. the pool on the beach) (Table 1) are benthic ciliates commonly found in the interstices of sandy sediments (see Fenchel 1964, Carey 1992 and references therein, Al-Rasheid 1996). 'Interstitial ciliates' is a broad term. Strictly speaking, it refers to flattened and ribbon-shaped ciliates adapted to glide over and within the interstitial habitat, and associated with the contour of each sand grain (Carey 1992). Most interstitial ciliates (e.g. the trachelocercids) are thigmotactic and contractile. The largest free-living ciliates ever described have been found gliding amongst sand grains, but many other ciliates thrive in this and other marine habitats (e.g. species of Cristigera, Cyclidium, Pleuronema, Strombidium, Uronema, and Uropedalium) and, as a result, the term 'interstitial ciliates' is fairly comprehensive.

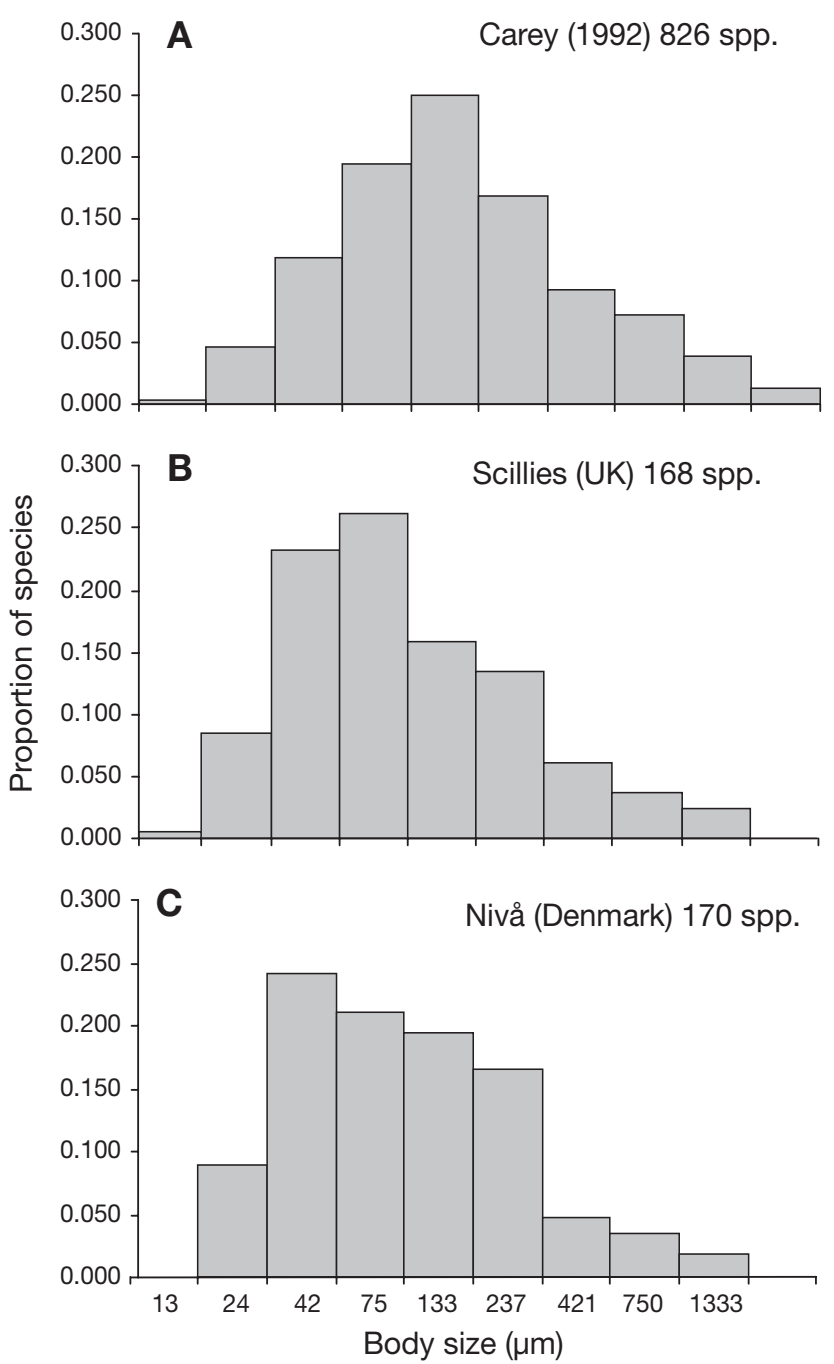

Fig. 4. Size frequency distributions for (A) all marine interstitial ciliate species (following Carey 1992; see 'Materials and methods'), (B) ciliate species recorded for rock pools on the Scillies, and (C) interstitial ciliate species recorded in Nivå Bay, Denmark (data from Finlay \& Fenchel 2004b). Body size is geometric mean for each size class

From the pools on the Bryher open-ocean rocks and St. Agnes beach, we also retrieved stalked ciliates, i.e. the peritrich genera Vorticella and Epistylis and the suctorian genera Acineta and Podophyra. Although not considered to occur in marine sands (Carey 1992), we consistently observed these genera after sediment from the pool had been allowed to settle for $24 \mathrm{~h}$. Sessile ciliates have been documented from marine sandy sediments before (Finlay \& Fenchel 2004b). Both groups of sessile ciliates have a free-swimming larval stage that enables them to move through sediment interstices similar to other benthic ciliates. Strombidium spp. and Rimostrombidium sp. (ciliate genera common in marine plankton) are also frequently observed in benthic interstitial sediments (Fenchel 1964, 
Carey 1992 and references therein, Al-Rasheid 1996, Fenchel et al. 1997). We too retrieved them from the sandy sediment of the rock-pools in our study. However, we did not record any truly planktonic ciliates, e.g. tintinnids. Our finding of 3 species of Peritromus (P. faurei, P. ovalis, and P. gigas) is also interesting. These 3 species were present in the rock pool on Bryher, but we failed to find any in the St. Agnes rock pool despite intensive search. Their apparent absence is most probably the result of inadequate sampling.

We recorded around 80 species of ciliates in each rock pool examined, so why did Fauré-Fremiet (1948) record so few ciliates in similar habitats? He found 15 species, along with a few others, small in number and size, which were not listed. There is no record of the time of year when his pools were sampled, although he did refer to extreme daily variations in temperature and salinity within the pools as a reason for low species richness, suggesting that the pools were examined in warm weather, and were small and shallow. Nevertheless, there may be other explanations. The rock pools may have lacked a layer of sandy sediment; however Fauré-Fremiet (1948) did observe Trachelocerca (Tracheloraphis) phoenicopterus, which is a typical inhabitant of sands. Alternatively, the sandy layer may not have been thick enough to support a greater ciliate diversity.

One of the main objectives of our investigation was to retrieve as many ciliate species as possible, including cryptic species or those present in such low numbers that they would normally escape detection, whereas Fauré-Fremiet wished to discover how a protozoan community can remain within the limits of a rock-pool environment that is flushed twice a day by the open sea. Thus, our sampling strategy included the use of a large range of vessels, tissue flasks, tubes, iceextraction etc., as well as enrichment techniques (see 'Materials and methods') - probably a very different approach from that of Fauré-Fremiet (1948). It is also possible that pristine and unspoiled environments such as the Isles of Scilly (Faubel \& Warwick 2005) support a richer protist diversity than more impacted areas.

To gain some idea of cryptic species richness in the 'seed bank', we plotted the cumulative number of species recorded in the 3 rock-pools over a $60 \mathrm{~d}$ period. We found more than 168 ciliate species (Fig. 5) and, of these, 135 were observed during our $5 \mathrm{~d}$ field investigation on the Scillies. The remaining species $(>30)$ were retrieved during the subsequent 2 mo period using enrichment cultures and other experimental manipulations that had previously proved successful in encouraging excystment and growth of undetected ciliate species (Finlay et al. 1996, Fenchel et al. 1997). The retrieval of 30 species over 2 mo seems fairly low, but this may be an artefact peculiar to marine samples,

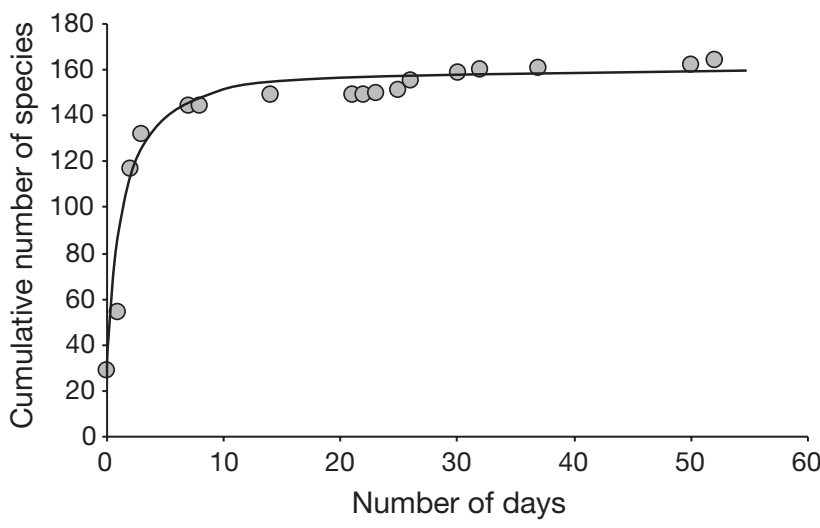

Fig. 5. Cumulative number of ciliate species observed in samples from intertidal rock pools in the Scillies and from enrichment cultures and enriched subsamples

which tend to decay more quickly than those from fresh waters.

The present study has shown that (1) intertidal rock pools can maintain diverse ciliate communities, (2) a relatively small-scale investigation of ciliates in rock pools yields a high local:global ratio of species, e.g. a shallow intertidal pool with a length $<1 \mathrm{~m}$ supported more than $20 \%$ of the global number of described marine interstitial ciliates. High local:global ratios are characteristic of small-sized organisms (Finlay \& Fenchel 2004a), and there are several examples in the recent literature to support this. Agamaliev (1983) and Alekperov \& Asadullaeva (1996) documented 351 species in the Caspian Sea, 318 ciliate species have been recorded in the Baltic (Agamaliev 1983), 450 benthic ciliate species have been documented from the Black Sea (Azovsky \& Mazei 2003), and Mazei \& Burkovskii (2005) reported 273 benthic ciliate species in the estuary of Chernaya River in the White Sea (Russia) over a 2 yr period.

Ciliates and other protists living in variable environments such as intertidal rock pools need to tolerate variable salinity, a degree of desiccation, and the pounding action of ocean waves. The heterogeneous ciliate communities in the rock pools of St. Agnes and Bryher share at least 2 characteristics. First, the species have all been recorded previously in other marine or saline environments worldwide (see e.g. Kahl 1935, Dragesco \& Dragesco-Kernéis 1986, Fenchel et al. 1995, Al-Rasheid 1996, Mazei \& Burkovsky 2005); second (as pointed out by Fauré-Fremiet 1948) they are able to sustain a diverse community despite regular wave action.

Ciliates in intertidal rock pools are closely associated with the surfaces of rocks and stones, creeping and sliding or attaching by means of a stalk. How do they escape removal by tidal waves? Many small organisms (e.g. Protozoa) are small enough to live within the ben- 
thic boundary layer, where they are subject to minimal drag. Moreover, typically 'flat' Protozoa such as the amoeba Vannella spp., the ciliate Chilodonella spp. and other organisms that lie adpressed to the substrate or creep over it, usually project no more than about $10 \mu \mathrm{m}$ above the surface, so that laminar flow is rarely affected. The same mechanism probably operates in running waters (Sylvester \& Sleigh 1985, Fenchel 1987). Baldock (1980) found a strong negative correlation between current velocity and the presence of peritrich ciliates. She also mentions a river in spate in which velocity increased to $70 \mathrm{~cm}$ $\mathrm{s}^{-1}$ and washed off most Vorticella spp., diatoms and algae. To ameliorate drag, it is probably advantageous for an organism to extend its body parallel to the substratum, as increased drag is more than compensated for by the increased contact area for adhesion (Sylvester \& Sleigh 1985, Fenchel 1987), especially in the case of organisms on an organic substrate, which offers much greater adhesive strength. As micro-organisms that live or creep on submerged surfaces do not project further than a few microns above the surface, and as the velocity of the water flow over the surfaces is virtually zero, the drag on microorganisms is probably negligible (Sylvester \& Sleigh 1985).

In conclusion, wave force in rock pools may not be sufficient to dislodge ciliates from submerged surfaces, but may be an obstacle to immigrants that do not possess suitable morphology. Thus, we did not find a single truly planktonic ciliate (e.g. tintinnids) in the samples, but we did find a strikingly large number of species with flat morphology. In the pool at St. Agnes $85 \%$ and at Bryher $75 \%$ of the species were flat or attached to a surface. Three species of Peritromus were found coexisting in the rock-pool at Bryher, where we also consistently observed P. gigas (a >200 $\mu \mathrm{m}$ long ciliate not reported since the study of FauréFremiet [1924], who found and described it in pelagic samples). Other ciliates were far larger and flatter than generally reported. Most remarkably, Aspidisca magna, a ciliate described by Kahl (1935) as having a body size of up to $135 \mu \mathrm{m}$, and with records rarely exceeding $150 \mu \mathrm{m}$, was almost $500 \mu \mathrm{m}$ long in our fresh field-collected samples. Dysteria appendiculata was twice its typical size, as were Uronychia transfuga, Diophrys scutum and Condylostoma arenarium. We also observed giant forms of D. scutum in laboratory cultures of samples taken from the Bryher rock pool that were trying to ingest large specimens of Aspidisca magna (Fig. 2H) and C. arenarium.
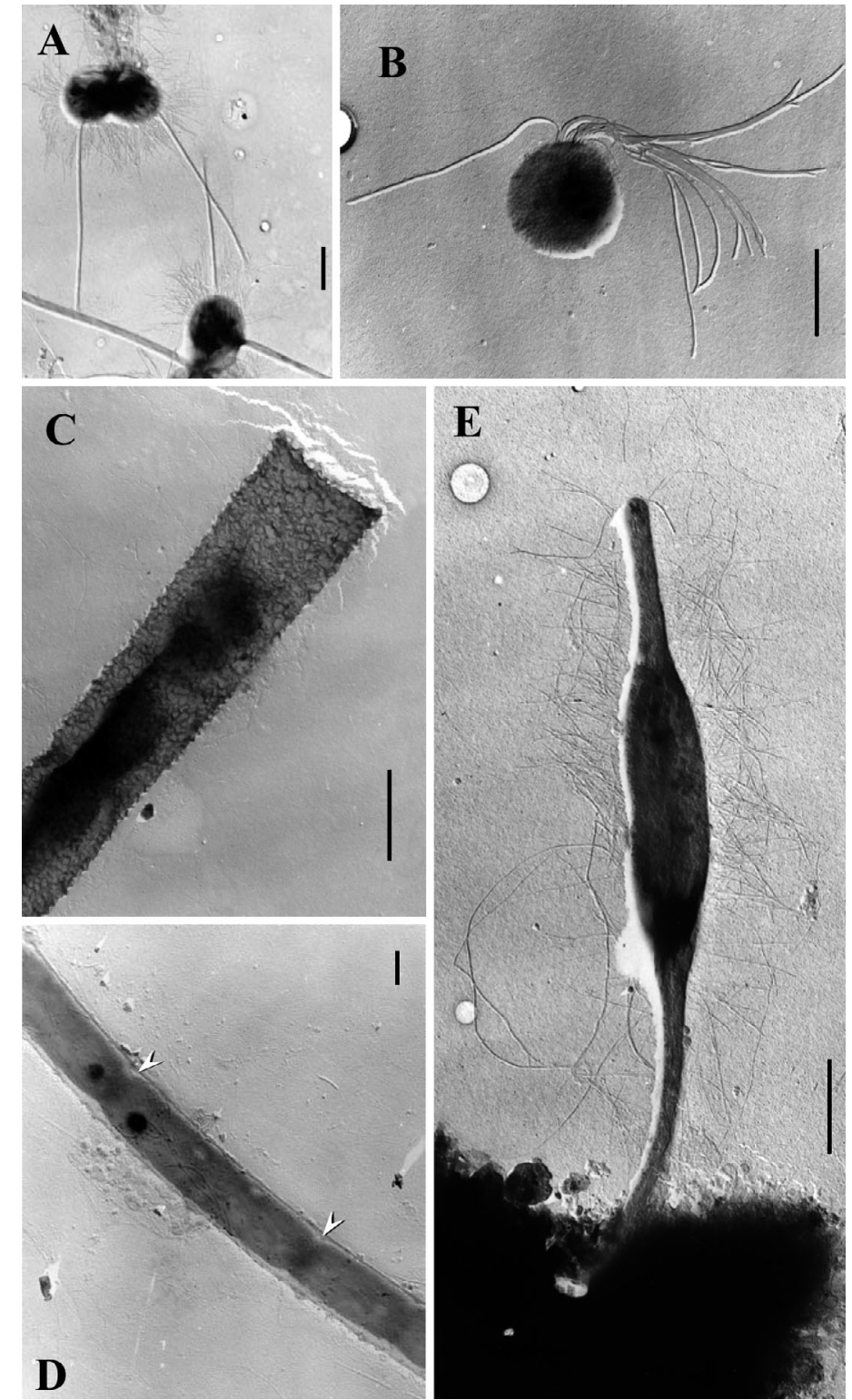

Fig. 6. Morphological diversity of some bacteria found in open-ocean intertidal rock pools in the Scillies. (TEM, shadow-cast direct preparations). (A) Types of stalked and peritrich bacteria (most common form of bacteria found in pristine intertidal rock pools investigated). (B) Common flagellated bacterium found in samples. $(C, D)$ Filamentous prokaryotes (probably not cyanobacteria) formed by envelope or capsule wrapped around the cell; (C) capsule is ornamented; (D) rod bacteria separated by septa (arrowheads) form filament protected by an 'envelope'. (E) Stalked bacterium, main part of cell (central part) is about $3 \mu \mathrm{m}$ long; this bacterial shape has also been found in fresh-

water sediments (K. J. Clarke pers. comm.). All scale bars $=1 \mu \mathrm{m}$

The body size and form of rock-pool ciliates, together with their tendency to adhere to surfaces and to migrate to the benthic boundary layer, may enable their continuous presence in rock pools. The fact that we also found some anaerobic ciliates (Sonderia spp., Plagiopyla 
frontata, Table 1) suggests that the sediment at the bottom of the pools is not regularly suspended during high tides and may represent a relatively stable and undisturbed habitat. There were no genuine plankton ciliates in the pools, suggesting that these are flushed out at high tide. Finally, food availability plays a significant role in the preservation of the resident rock-pool ciliate populations: electron microscopy revealed that subsamples from the Bryher open-ocean rock pool contained a rich community of stalked and peritrichous bacteria (Fig. 6), a food supply that withstands tidal flushing.

Ciliates are apparently capable of remaining in rock pools because of their typically flattened morphology, and their affiliation with the benthic boundary layer. Continuous development of attached bacteria may serve as their principal food source. The ciliates living in the rock-pools were almost all confined to the surface of rocks and the bottom layer of sandy sediment. This might explain the existence of a diverse 'resident' ciliate community which underpins the high species richness. Unfortunately there does not seem to be any other similar study with which we can compare our results. It is strange that one of the most accessible marine environments is also one of the least understood.

Acknowledgements. We thank R. M. Warwick and P. J. Somerfield (Plymouth Marine Laboratory, UK) for field support and logistics on the Isles of Scilly; K. J. Clarke (Freshwater Biological Association, UK) for analyses of samples using transmission electron microscopy; and the Natural Environment Research Council (UK) for financial support. This work was funded in part by the Department for Environment Food and Rural Affairs, UK (ME3109). This article benefited greatly from the comments and suggestions of 2 anonymous reviewers.

\section{LITERATURE CITED}

Agamaliev FG (1983) Ciliates of the Caspian Sea: systematics, ecology, zoogeography. Nauka, Leningrad (in Russian)

Alekperov IH, Asadullaeva ES (1996) New and rare ciliates of Absheron coast of the Caspian Sea. Zool Zh 75:763-769 (in Russian with English Summary)

Al-Rasheid KAS (1996) Records of free-living ciliates in Saudi Arabia. I. Marine interstitial ciliates of the Arabian Gulf Islands of Al-Bātinah and Abū Ali. Arab Gulf J Sci Res 14:747-765

Azovsky AI, Mazei YA (2003) A conspectus of the Black Sea fauna of benthic ciliates. Protistology 3:72-91

Baldock BM (1980) The ecology of protozoa in chalk streams, with particular reference to ciliates and amoebae associated with selected macrophytes. PhD thesis, University of Southampton, UK

Carey PG (1992) Marine interstitial ciliates. An illustrated key. Natural History Museum Publications, Chapman \& Hall, London

Dragesco J (1999) Revision des Geléiides (Ciliophora, Karyorelictea). Stapfia 66:1-91

Dragesco JA, Dragesco-Kernéis A (1986) Ciliés libres de l'Afrique intertropical. Introduction à la connaissance et

Editorial responsibility: Fereidoun Rassoulzadegan (Contributing Editor), Villefranche-sur-Mer, France à l'étude des Ciliés. Collection faune tropicale, 26, ORSTOM, Paris

Esteban GF, Finlay BJF (2004) Marine ciliates (Protozoa) in central Spain. Ophelia 58:1-10

Esteban GF, Clarke KJ, Finlay BJ (1998) Rapid techniques for the identification of free-living protozoa. In: Burlage RS, Atlas R, Stahl D, Geesey G, Sayler G (eds) Techniques in microbial ecology. Oxford University Press, Oxford, p 203-217

Faubel A, Warwick RM (2005) The marine flora and fauna of the Isles of Scilly: free-living Platyhelminthes ('Turbellaria'). J Nat Hist 39:1-45

Fauré-Fremiet E (1924) Contribution à la connaissance des infusoires planktoniques. Bull Biol Fr Belg 4(Suppl):1-171

Fauré-Fremiet E (1948) The ecology of some infusorian communities of intertidal pools. J Anim Ecol 17:127-130

Fenchel T (1964) The ecology of marine microbenthos. IV. Structure and function of the benthic ecosystem, its chemical and physical factors and the microfauna communities with special reference to the ciliated Protozoa. Ophelia 6: $1-182$

Fenchel T (1987) Ecology of protozoa: the biology of freeliving phagotrophic protists. Springer-Verlag, Berlin

Fenchel T, Bernard C, Esteban G, Finlay BJ, Hansen PJ, Iversen N (1995) Microbial diversity and activity in a Danish fjord with anoxic deep water. Ophelia 43:45-100

Fenchel T, Esteban GF, Finlay BJ (1997) Local versus global diversity of microorganisms: cryptic diversity of ciliated protozoa. Oikos 80:220-225

Fernández-Galiano D (1994) The ammoniacal silver carbonate method as a general procedure in the study of protozoa from sewage (and other) waters. Water Res 28:495-496

Finlay BJ, Fenchel T (2004a) Cosmopolitan metapopulations of free-living microbial eukaryotes. Protist 155:237-244

Finlay BJ, Fenchel T (2004b) Cosmopolitan metapopulations of free-living microbial eukaryotes. Supplementary information. Protist 155:e1-e38

Finlay BJ, Esteban GF, Fenchel T (1996) Global diversity and body size. Nature 383:132-133

Hartwig E (1980) A bibliography of the interstitial ciliates (Protozoa): 1926-1979. Arch Protistenkd 123:422-438

Jonsson PR (1994) Tidal rhythm of cyst formation in the rock pool ciliate Strombidium oculatum Gruber (Ciliophora, Oligotrichida) - a description of the functional biology and an analysis of the tidal synchronization of encystment. J Exp Mar Biol Ecol 175:77-103

Kahl A (1935) Urtiere oder Protozoa. I. Wimpertiere oder Ciliata (Infusoria). Eine Bearbeitung der freilebenden und ectocommensalen Infusorien der Erde, unter Ausschluß der marinen Tintinnidae. Vier Teile. In: Dahl F (ed) Die Tierwelt Deutschlands und der angrenzenden Meeresteile. Gustav Fischer, Jena, p 1-886

Mazei YA, Burkovsky IV (2005) Species composition of benthic ciliate community in the Chernaya River estuary (Kandalaksha Bay, White Sea) with a total checklist of the White Sea benthic ciliate fauna. Protistology 4:107-120

Montagnes DJS, Wilson D, Brooks SJ, Lowe C, Campey M (2002) Cyclical behaviour of the tide-pool ciliate Strombidium oculatum. Aquat Microb Ecol 28:55-68

Sylvester NR, Sleigh MA (1985) The forces on microorganisms at surfaces in flowing water. Freshw Biol 15:433-448

Uhlig G (1966) Untersuchungen zur Extraktion vagilen Mikrofauna aus marinen Sedimenten. Zool Anz 29 (Suppl):151-157

UKNCC (2001) Catalogue of the National Culture Collection (UKNCC). List of Algae and Protozoa. Dunstaffnage Marine Laboratory, Oban

Submitted: August 25, 2006; Accepted: November 3, 2006 Proofs received from author(s): March 14, 2007 